\title{
Hypersecretion of zymogen granules in the pathogenesis of cystic fibrosis ${ }^{1}$
}

\author{
JEANETTE BLOMFIELD, J. DASCALU, E. W. van LENNEP, AND J. M. BROWN \\ From the Children's Medical Research Foundation and Cystic Fibrosis Clinic, Royal Alexandra Hospital for \\ Children, Camperdown, and Department of Histology and Embryology, University of Sydney, New South \\ Wales, Australia
}

SUMMARY In the submandibular saliva of 10 cystic fibrosis subjects and 10 controls the turbidity and elevated calcium, protein, and amylase concentrations of the cystic fibrosis secretions, and precipitation of calcium and phosphate in a ratio consistent with hydroxyapatite have been confirmed. By electron microscopy the centrifuged deposits of the cystic fibrosis saliva were seen to be composed predominantly of round or oval subcellular corpuscles. By comparison with submandibular gland, these corpuscles have been identified as inclusion bodies (spherules) from within zymogen granules. Hydroxyapatite crystals formed on standing in the cystic fibrosis saliva. Polyacrylamide gel disc electrophoresis of the cystic fibrosis centrifuged deposits showed five bands, one of which, band 4, was more prominent in the deposit than in the supernatant gels.

Comparisons have been made between these results and other studies and have shown (1) elevated calcium and protein in cystic fibrosis exocrine secretions; (2) simultaneous secretion of calcium and enzymes from salivary glands, stomach, and pancreas; and (3) increased salivary secretion of calcium and protein in response to parasympathomimetic and sympathomimetic drugs.

Hypersecretion of calcium-containing zymogen granules is postulated as the cause of obstruction in cystic fibrosis.

Cystic fibrosis of the pancreas is a generalized disorder affecting all of the exocrine glands. The submandibular saliva is turbid compared with the clear saliva of controls, and has raised concentrations of calcium, protein, and the enzymes amylase and acid and alkaline ribonucleases (Chernick, Barbero, and Parkins, 1961 ; Chernick, Eichel, and Barbero, 1964). Because of the elevated calcium level the solubility limit of $\left(\mathrm{Ca}^{2+}\right) \times\left(\mathrm{HPO}_{4}{ }^{2-}\right)$ is exceeded, and calcium is precipitated as hydroxyapatite (Warton and Blomfield, 1971).

The concentration of calcium in cystic fibrosis submandibular saliva often exceeds the level of ionized calcium in the plasma, therefore a dual mechanism of calcium secretion from both interstitial fluid and from zymogen granules has been proposed (Blomfield, 1972; Blomfield, Warton, and Brown, 1973). Supportive evidence of cosecretion of calcium

1Supported in part by a grant from the Cystic Fibrosis Association of NSW.

Received for publication 23 March 1973 and enzymes has come from studies of rat parotid gland (Wallach and Schramm, 1971), human gastric juice (Moore and Makhlouf, 1968), human duodenal fluid (Goebell, Bode, and Horn, 1970), and canine pancreatic juice (Goebell, Steffen, and Bode, 1972).

Light microscope examination of the turbidity of cystic fibrosis submandibular saliva had shown small, round particles at the limit of resolution of the microscope (Blomfield, 1972). To identify these particles, the centrifuged deposits were examined by electron microscopy and compared with the submandibular gland.

The electrophoretic pattern of the centrifuged deposit has been compared with studies of the calcium-precipitable protein of submandibular saliva (Gugler, Pallavicini, Swerdlow, and di Sant'Agnese, 1967; Boat, 1970).

\section{Subjects and Methods}

Citric acid-stimulated submandibular saliva was collected by a modification of the method of Mandel, 
Eriv, Kutscher, Denning, Thompson, Kessler, and Zegarelli (1969), as previously outlined (Blomfield et al, 1973). The subjects were 10 patients with cystic fibrosis aged from 6 to 15 years (five male and five female), and from 10 healthy controls aged from 8 to 19 years (five male and five female).

The turbidity was separated in aliquots of the saliva by centrifugation at $37000 \mathrm{~g}$ and $2^{\circ}$ for 30 minutes in a Sorvall RC2-B superspeed centrifuge. The deposits were dissolved in a volume equal to the original aliquot volume of $4 \mathrm{~N}$ hydrochloric acid for calcium, inorganic phosphate, and protein (then neutralized by $4 \mathrm{~N}$ sodium hydroxide for protein estimation), and in five times the original volume of $0.9 \%$ sodium chloride for the amylase estimations. Calcium was measured by the atomic absorption spectrophotometric method of Gow (1965) using lanthanum $5000 \mathrm{ppm}$ as diluent. Inorganic phosphate was determined by the ascorbic acid-molybdate method of Chen, Toribara, and Warner (1956). Protein was estimated by the method of Lowry, Rosebrough, Farr, and Randall (1951), with replacement of tartrate by citrate for greater stability as modified by Eggstein and Kreutz (1955). Amylase was assessed by the dyed polysaccharide method of Klein, Foreman, and Searcy (1970) (Amylochrome kit, Roche Diagnostics, New Jersey).

For electron microscopy the centrifuged deposits from $0.2 \mathrm{ml}$ aliquots of the submandibular saliva were fixed with $2 \%$ glutaraldehyde in $0.1 \mathrm{M}$ phosphate buffer, $\mathrm{pH} 7 \cdot 2$, for two hours at $2^{\circ}$ (fig 1 ). To demonstrate hydroxyapatite crystal formation, aliquots were left in vitro for one hour at $20^{\circ}$ before centrifugation, and the centrifuged deposits were fixed in $2 \%$ glutaraldehyde in $0.1 \mathrm{M}$ cacodylate buffer,

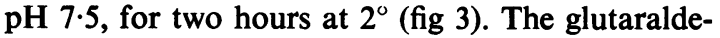
hyde-fixed deposits were washed twice in the appropriate buffer, postfixed for 30 minutes in $1 \%$ osmium tetroxide, washed once in water, then stained for 60 minutes in $1 \%$ uranyl acetate. The deposits were then dehydrated in ethanol, increasing from 70 to $100 \%$ and embedded in Araldite.

A submandibular gland was obtained at necropsy from an 11-year-old boy with cystic fibrosis. It was fixed overnight in $2.5 \%$ glutaraldehyde, buffered with cacodylate, and postfixed for one hour in $2 \%$

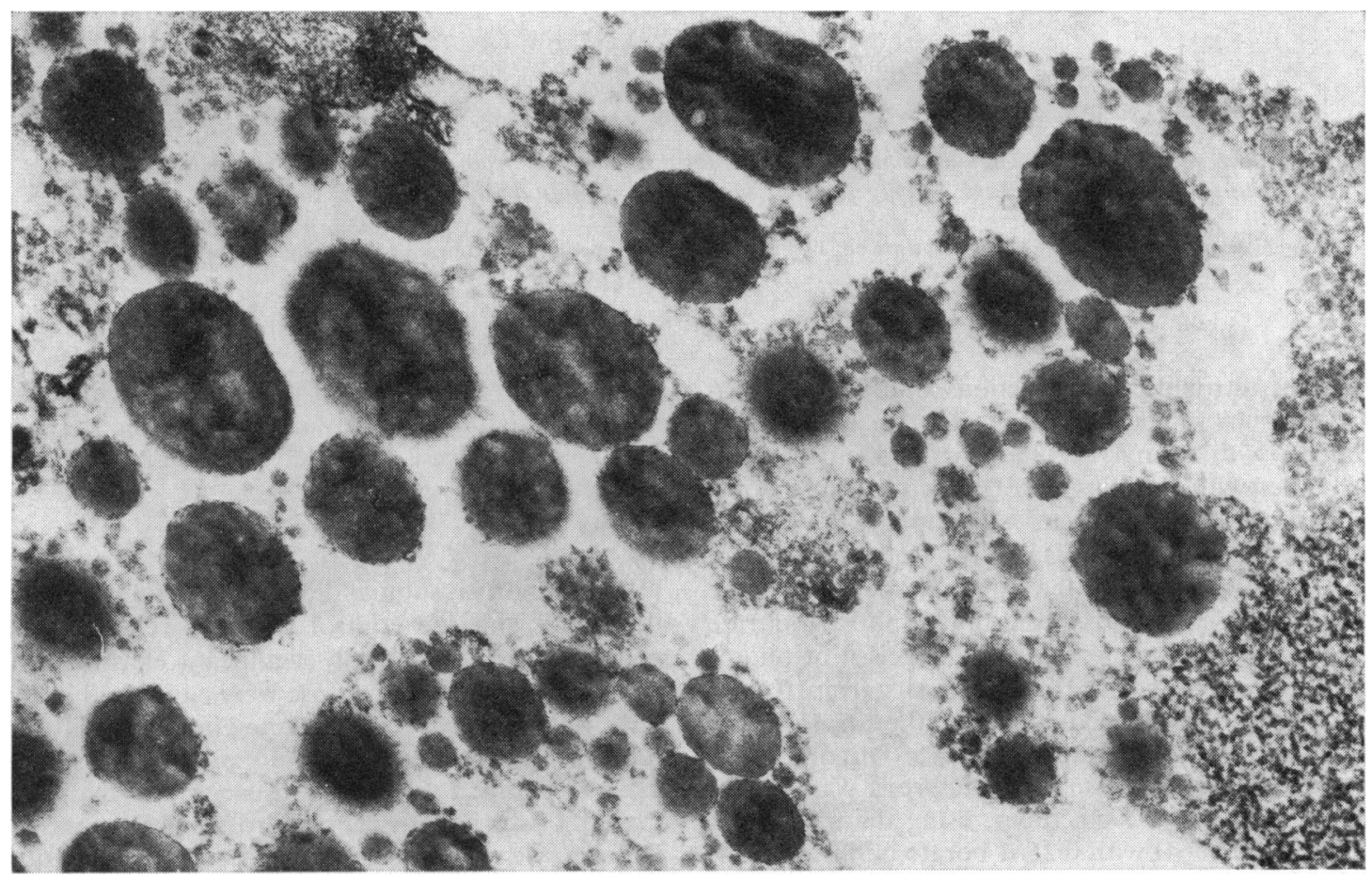

Fig $1^{1} \quad$ Electron micrograph of zymogen granule spherules and finely granular matrix (lower right corner) in the centrifuged deposit of turbid cystic fibrosis submandibular saliva. $\times 42000$. 


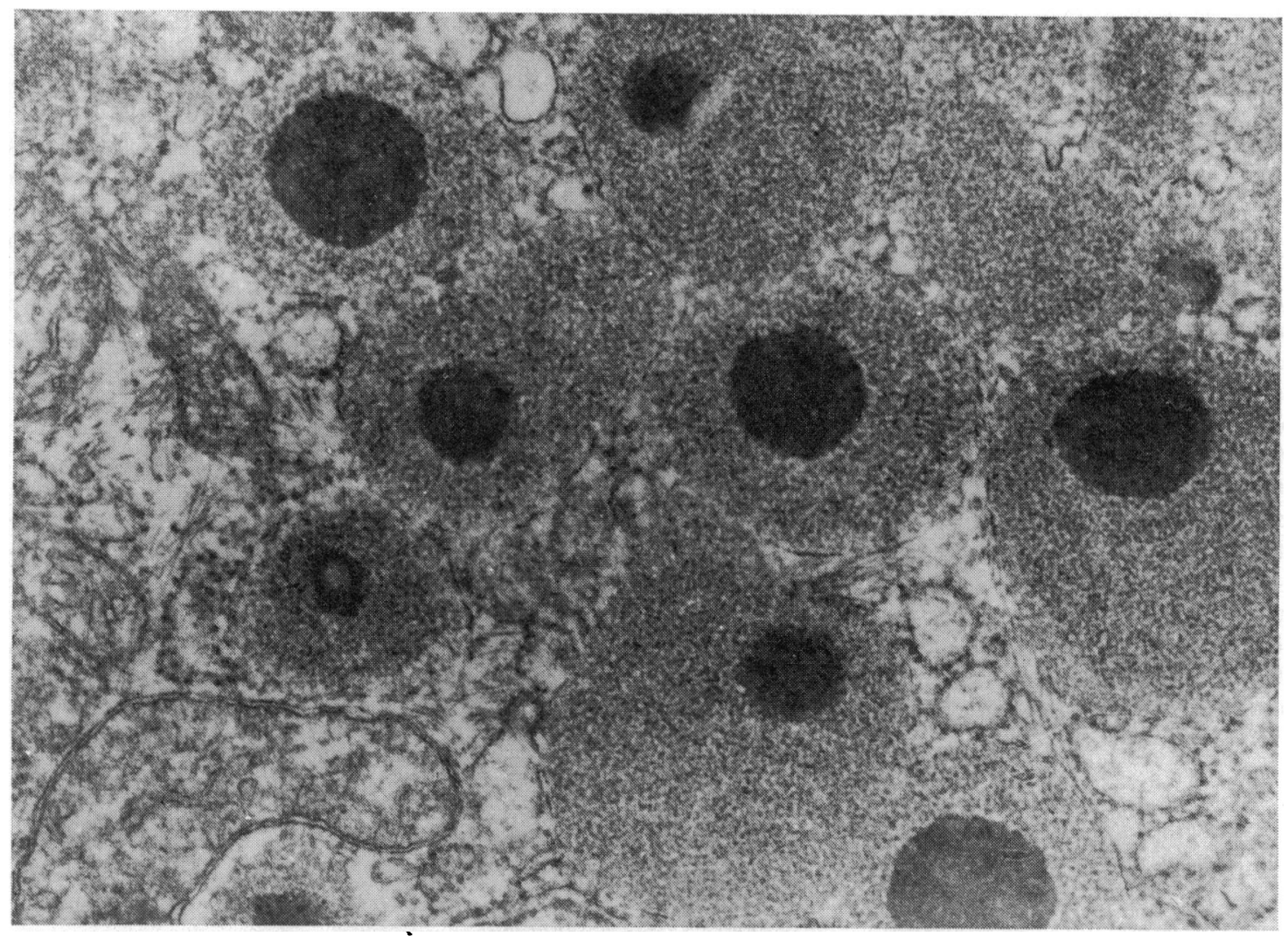

Fig $2^{2}$ Electron micrograph of submandibular gland obtained at necropsy from an 11-year-old boy with cystic fibrosis. The zymogen granules have a finely granular matrix and contain an inclusion body or spherule. $\times 42000$.

2Submandibular gland prepared for electron microscopy by Professor D. A. Cameron, Department of Pathology, University of Sydney.

osmium tetroxide. Thin sections of both the submandibular saliva deposits and the gland were stained with uranyl acetate and lead citrate, and examined with a Phillips EM 300 electron microscope.

For polyacrylamide gel electrophoresis, $0.2 \mathrm{ml}$ samples of submandibular saliva were centrifuged, and $0.15 \mathrm{ml}$ of both the supernatant and of the deposit (which was dissolved in $0.2 \mathrm{ml} 0.1 \mathrm{M}$ citrate buffer, pH 7.2) were applied to the gels. For photographic purposes (fig 4) the deposits from $0.5 \mathrm{ml}$ samples were dissolved in $0.2 \mathrm{ml}$ of the citrate buffer, and $0.15 \mathrm{ml}$ of this applied to the gels. Discontinuous polyacrylamide gel disc electrophoresis was carried out in standard $7.5 \mathrm{~cm}$ tubes, using the method of Pallavicini (1964) with 0.25M borate buffer, pH 8.4. After fixation in $47 \%$ methanol, $47 \%$ water, and $6 \%$ acetic acid for $\mathbf{3 0}$ minutes, the gels were stained for 30 minutes in $0.5 \%$ amido black in $5 \%$ acetic acid. The gels were destained for one to two days in $7 \%$ acetic acid in a Gradipore ${ }^{1}$ destainer, in which the acetic acid is continuously circulated over the gels and the eluted dye is adsorbed by wool pellets.

\section{Results}

The cystic fibrosis submandibular saliva samples were all turbid, and the control samples were clear or slightly turbid. Statistically significant elevations of calcium, protein, and amylase were confirmed in the cystic fibrosis saliva (see table), and in the centrifuged deposits the raised calcium and inorganic phosphate levels conformed to ratios consistent with hydroxyapatite. Cystic fibrosis deposit protein was increased. The amylase was almost entirely in the supernatant.

By electron microscopy the centrifuged deposits

${ }^{1}$ Gradipore destainer, Townson and Mercer (Distributors) Pty Ltd, 318 Burns Bay Road, Lane Cove, NSW 2066, Australia. 


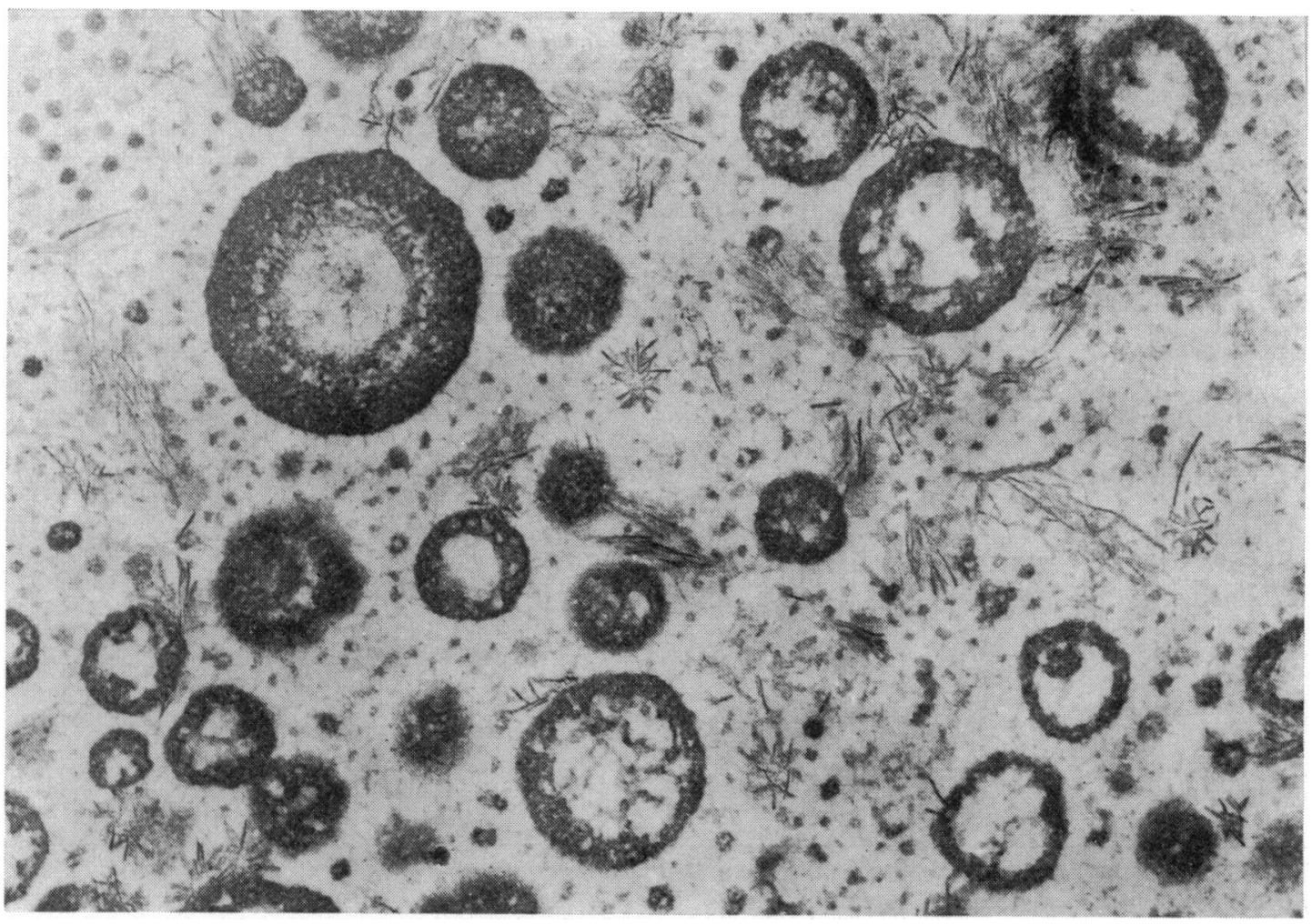

Fig 3 Electron micrograph of hydroxyapatite crystals and disintegrating spherules in the centrifuged deposit of cystic fibrosis submandibular saliva, which had been left at $20^{\circ}$ for one hour before fixation by $2 \%$ glutaraldehyde in cacodylate buffer. $\times 42000$.

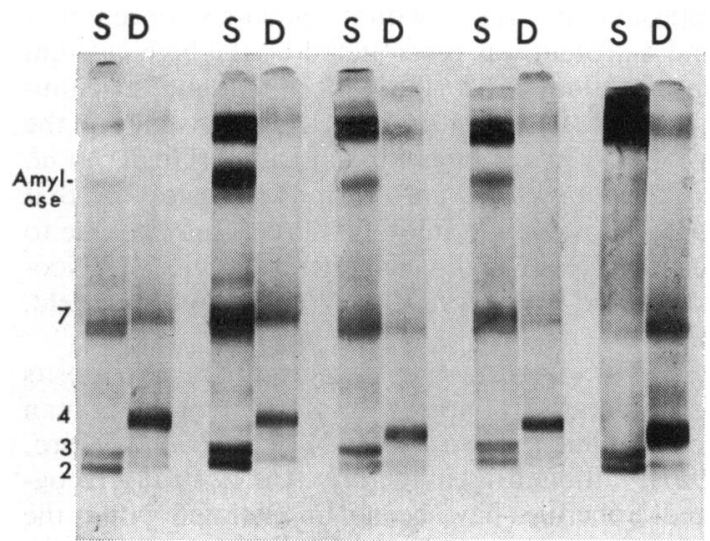

Fig 4 Polyacrylamide gel electrophoresis of supernatant (S) and centrifuged deposit (D) of the submandibular saliva of five children with cystic fibrosis.

of the turbid cystic fibrosis submandibular saliva were found to consist predominantly of round or oval corpuscles (fig 1). By comparison with electron micrographs of the submandibular gland these corpuscles were identified by size, general appearance, and electron density as the inclusion bodies, or spherules (Tandler and Erlandson, 1972), from within the zymogen granules (fig 2). Spherules were abundant in all cystic fibrosis saliva preparations and rare in the control samples. The cystic fibrosis deposits also contained finely granular material (fig 1) which resembled the matrix of the zymogen granules (fig 2).

On standing in vitro many of the cystic fibrosis saliva deposits showed masses of fine, needle crystals of hydroxyapatite and partial disintegration of the spherules (fig 3 ). The crystals were usually separate from the spherules.

Polyacrylamide gel disc electrophoresis of the centrifuged deposits showed five bands, namely, bands 2, 3, 4, and 7, and an unnumbered band near the origin (nomenclature of Gugler et al, 1967). Band 4 was the heaviest staining deposit band, and the only one which was more prominent in the deposit than in the supernatant gels (fig 4). The amylase 


\begin{tabular}{|c|c|c|c|c|c|c|c|c|c|}
\hline \multirow[t]{2}{*}{ Age } & \multirow[t]{2}{*}{$\operatorname{Sex}$} & \multicolumn{4}{|c|}{ Total Submandibular Saliva } & \multicolumn{4}{|c|}{ Centrifuged Deposit } \\
\hline & & $\begin{array}{l}\mathrm{Ca}^{2+} \\
(\text { m-equiv } / l)\end{array}$ & $\begin{array}{l}\text { HPOQ } \\
\text { (m-equiv/l) }\end{array}$ & $\begin{array}{l}\text { Protein } \\
(\mathrm{mg} / 100 \mathrm{ml})\end{array}$ & $\begin{array}{l}\text { Amylase } \\
\text { (dye units/ } \\
100 \mathrm{ml})\end{array}$ & $\begin{array}{l}\mathrm{Ca}^{2+} \\
(\mathrm{m} \text {-equiv/l) }\end{array}$ & $\begin{array}{l}\mathrm{HPO}_{4}^{2-} \\
\text { (m-equiv|l) }\end{array}$ & $\begin{array}{l}\text { Protein } \\
(\mathrm{mg} / 100 \mathrm{ml})\end{array}$ & $\begin{array}{l}\text { Amylase } \\
(\text { dye units } / \\
100 \mathrm{ml})\end{array}$ \\
\hline \multicolumn{10}{|c|}{ Cystic Fibrosis Patients } \\
\hline $\begin{array}{r}6 \\
7 \\
7 \\
7 \\
7 \\
10 \\
11 \\
13 \\
15 \\
15\end{array}$ & $\begin{array}{l}\mathbf{M} \\
\mathbf{F} \\
\mathbf{F} \\
\mathbf{F} \\
\mathbf{M} \\
\mathbf{F} \\
\mathbf{F} \\
\mathbf{M} \\
\mathbf{M} \\
\mathbf{M}\end{array}$ & $\begin{array}{l}5.0 \\
5 \cdot 7 \\
4 \cdot 5 \\
4.8 \\
5.9 \\
4 \cdot 8 \\
4.3 \\
7 \cdot 0 \\
4.2 \\
9.0\end{array}$ & \begin{tabular}{r|}
6.4 \\
4.6 \\
6.7 \\
4.2 \\
5.8 \\
3.8 \\
3.0 \\
10.6 \\
5.8 \\
7.4
\end{tabular} & $\begin{array}{l}123 \\
162 \\
131 \\
205 \\
160 \\
196 \\
178 \\
173 \\
132 \\
246\end{array}$ & $\begin{array}{r}156500 \\
67300 \\
60700 \\
120000 \\
167500 \\
150000 \\
84200 \\
122800 \\
42500 \\
126100\end{array}$ & $\begin{array}{l}2.1 \\
2.2 \\
3.0 \\
2.2 \\
3.0 \\
0.8 \\
1.9 \\
2.6 \\
0.5 \\
1.0\end{array}$ & $\begin{array}{l}1.6 \\
1.4 \\
2.3 \\
1.6 \\
1.6 \\
0.0 \\
0.3 \\
2 \cdot 2 \\
0.0 \\
0.3\end{array}$ & $\begin{array}{l}29 \\
52 \\
29 \\
45 \\
40 \\
36 \\
64 \\
29 \\
34 \\
86\end{array}$ & $\begin{array}{r}1500 \\
5800 \\
3200 \\
10000 \\
5000 \\
5000 \\
9200 \\
5300 \\
2500 \\
8600\end{array}$ \\
\hline $\begin{array}{l}\text { Mean } \\
\text { SD }\end{array}$ & & $\begin{array}{r}5.5 \\
\pm 1 \cdot 4\end{array}$ & $\begin{array}{r}5.8 \\
\pm 2.1\end{array}$ & $\begin{array}{r}171 \\
\pm \quad 37\end{array}$ & $\begin{array}{r}109860 \\
\pm \quad 41200\end{array}$ & $\begin{array}{r}1.9 \\
\pm 0.9\end{array}$ & $\begin{array}{r}1.2 \\
\pm 0.9\end{array}$ & $\begin{array}{r}44 \\
\pm 18\end{array}$ & $\begin{array}{r}5610 \\
+\quad 2910\end{array}$ \\
\hline \multicolumn{10}{|c|}{ Control Subjects } \\
\hline $\begin{array}{l}8 \\
10 \\
10 \\
11 \\
12 \\
13 \\
18 \\
19 \\
19 \\
19\end{array}$ & $\begin{array}{l}\mathbf{M} \\
\mathbf{M} \\
\mathbf{F} \\
\mathbf{F} \\
\mathbf{M} \\
\mathbf{F} \\
\mathbf{F} \\
\mathbf{F} \\
\mathbf{M} \\
\mathbf{M}\end{array}$ & $\begin{array}{l}2.1 \\
2.6 \\
1.8 \\
1.4 \\
2.2 \\
1.9 \\
3.0 \\
2.6 \\
3.5 \\
2.4\end{array}$ & $\begin{array}{l}\mathbf{6 . 7} \\
6 \cdot 5 \\
2 \cdot 5 \\
3 \cdot 3 \\
6 \cdot 0 \\
6 \cdot 3 \\
4 \cdot 8 \\
3 \cdot 4 \\
6 \cdot 7 \\
6 \cdot 7\end{array}$ & $\begin{array}{r}116 \\
146 \\
50 \\
74 \\
91 \\
109 \\
97 \\
100 \\
144 \\
127\end{array}$ & $\begin{array}{r}31900 \\
53100 \\
42100 \\
48300 \\
47300 \\
53200 \\
29400 \\
3500 \\
45100 \\
44200\end{array}$ & $\begin{array}{l}0.2 \\
0.5 \\
0.3 \\
0.3 \\
0.7 \\
0.5 \\
0.4 \\
0.4 \\
0.3 \\
0.2\end{array}$ & $\begin{array}{l}0.3 \\
0.6 \\
0.4 \\
0.4 \\
0.6 \\
0.3 \\
0.4 \\
0.2 \\
0.3 \\
0.3\end{array}$ & $\begin{array}{r}38 \\
39 \\
0 \\
10 \\
17 \\
17 \\
16 \\
22 \\
30 \\
19\end{array}$ & $\begin{array}{r}1950 \\
3150 \\
2150 \\
2300 \\
2300 \\
3200 \\
950 \\
150 \\
2300 \\
2250\end{array}$ \\
\hline $\begin{array}{l}\text { Mean } \\
\text { SD } \\
\text { P }\end{array}$ & & $\begin{aligned} & 2.4 \\
\pm & 0.6 \\
< & 0.001\end{aligned}$ & $\begin{array}{r}5.3 \\
+1.7 \\
\text { NS }\end{array}$ & $\begin{aligned} & 105 \\
\pm & 29 \\
< & 0.001\end{aligned}$ & $\begin{array}{r}39810 \\
+\quad 15000 \\
<0.001\end{array}$ & $\begin{array}{c}0.4 \\
\pm 0.1 \\
<0.001\end{array}$ & $\begin{array}{c}0.4 \\
\pm 0.1 \\
<0.01\end{array}$ & $\begin{aligned} & 21 \\
\pm & 12 \\
< & 0.01\end{aligned}$ & $\begin{array}{r}2070 \\
\pm \quad 920 \\
<0.001\end{array}$ \\
\hline
\end{tabular}

Table Calcium, inorganic phosphate, protein, and amylase values for citric acid-stimulated submandibular saliva of cystic fibrosis patients and control subjects

region (Mandel, Kutscher, Denning, Thompson, and Zegarelli, 1967b), although clearly discernible in the cystic fibrosis supernatant gels, was not detected in the deposit gels.

In the control deposit gels, the only bands observed were bands 2 and 3 in two of the 10 samples.

\section{Discussion}

The turbidity of cystic fibrosis submandibular saliva has been shown by electron microscopy to be caused by masses of undissolved zymogen granule spherules and precipitated hydroxyapatite. This finding is in agreement with the known elevation of calcium, protein, and amylase in this saliva (Chernick et al, 1961 and 1964), and with the chemical and $x$-ray powder diffraction evidence of hydroxyapatite in the centrifuged deposit (Warton and Blomfield, 1971). These results are consistent with the concept that calcium is stored in and secreted by the zymogen granules, and that the elevated calcium level in cystic fibrosis submandibular saliva is derived from an oversecretion of zymogen granules, as previously proposed (Blomfield, 1972; Blomfield et al, 1973).

The consistent presence of the electrophoretic bands 2,3 , and 4 in the cystic fibrosis deposits suggests that these unidentified bands may represent undissolved components (spherules and matrix) of zymogen granules in the submandibular saliva. This proposal is at variance with the previous concept that band 4 protein was precipitated by the high calcium concentration, and that the resultant calciumphosphoprotein aggregates were responsible for the turbidity of the submandibular saliva (Gugler et al, 1967; Boat, 1970), and with the suggestion that mucous obstruction in cystic fibrosis may be due to the presence of highly polymerized units of glycoprotein and hydroxyapatite (Warton and Blomfield, 1971).

Spherules were observed in the centrifuged deposits of comparatively large volumes of normal human submandibular saliva by Caldwell and Shackleford, (1967), although their identity was not fully recognized. Spherules have been demonstrated within the zymogen granules of the human submandibular gland by Ferner and Gansler (1961) and by Sato, Noguchi, Yokoyama, and Yotsumoto (1966). The latter study showed extrusion of zymogen granule contents into the lumen of the duct, which contained a number of intact, free-floating spherules. Tandler and Erlandson (1972), using glutaraldehyde fixation, demonstrated that the human submandibular 
serous granules contained a round or oval spherule, a finely granular matrix, and often, crescent-shaped material of intermediate density.

The diversity of fine structure of submandibular serous granules of different mammalian species has been shown in a study by Dorey and Bhoola (1972). In human glands, inclusion bodies have been noted in parotid granules (Orzalesi, Riva, and Testa, 1971) but not in lacrimal secretory granules (Orzalesi et al, 1971) nor in pancreatic zymogen granules (Kern and Ferner, 1971), both of which have a homogeneous or finely granular structure.

Because of the diversity of zymogen granules in different species and in different glands, it is difficult to extrapolate from one to another. There is, however, growing evidence suggesting that in the alimentary secretion of enzymes, calcium is a frequent component of the serous secretions. In rat parotid gland slices Wallach and Schramm (1971) have shown a concomitant secretion of calcium and protein, with an approximately constant ratio of calcium to amylase. On subcellular fractionation of the gland the secretory granules had the highest calcium-protein ratio, which was identical to the calcium/protein ratio of material secreted in vitro from isolated slices of the glands.

In human gastric juice, Moore and Makhlouf (1968) have postulated a four-component secretion of calcium in which three fractions-ionized calcium, albumin-bound calcium, and complexed calciumare derived from the interstitial (nonparietal) fluid, and in which the fourth calcium fraction is secreted by the chief cells and is thought to be bound to, or associated with, pepsinogen.

In canine pancreatic juice, Goebell et al (1972) found that pancreozymin-cholecystokinin stimulated the secretion of both calcium and enzyme protein in a parallel and closely correlated fashion. The activities of both trypsin and lipase in this stimulated juice were both strictly proportional to the protein concentration. A second calcium fraction which was independent of protein secretion and which was released by secretin stimulation, was thought to originate in the interstitial fluid. Zimmerman, Dreiling, Rosenberg, and Janowitz (1967) had earlier concluded from combined secretin and pancreozymin stimulation studies of pancreatic juice in dogs that calcium secretion might be associated with that of amylase. Goebell et al (1970) had found in normal human duodenal juice a similar parallelism between calcium and pancreatic enzyme secretion in response to pancreozymin stimulation.

The mammary gland is an exocrine gland which produces a secretion particularly rich in calcium and the associated phosphoprotein, caseinogen. By electron microscopy the centrifuged deposit of rat milk is composed predominantly of secretion granules, which have lost their membranes, but which have retained their spherical shape and regular network pattern (Carlsson and Karlsson, 1972).

In cystic fibrosis secretions, in addition to the submandibular saliva, calcium and protein are increased in tracheobronchial secretions (Chernick and Barbero, 1959), in the meconium of meconium ileus (Kopito and Shwachman, 1966; Green, Clarke, and Shwachman, 1958), and in the seminal plasma (Rule, Kopito, and Shwachman, 1970). A single duodenal fluid sample tested had an elevated calcium level (Kopito and Shwachman, 1964). Enzyme concentrations are high in submandibular saliva (Chernick et al, 1961; Mandel et al, 1967b) and in pancreozymin-secretin-stimulated duodenal fluid of cystic fibrosis patients without clinical pancreatic insufficiency (Hadorn, Johansen, and Anderson, 1968), and in parents of cystic fibrosis children, pancreatic enzyme activities are significantly higher than in other adults (Neal, Girgis, and Belmonte, 1972). These results are consistent with a simultaneous secretion of calcium and enzymes, and with hyperactivity of serous cell secretion in cystic fibrosis.

There is a growing volume of evidence suggesting a malfunction of the autonomic nervous system in the exocrine glands in cystic fibrosis. This evidence has been reviewed by Barbero and Chernick (1966) and by di Sant'Agnese and Talamo (1967). Farber $(1942,1945)$ induced pancreatic achylia with histological changes characteristic of the disease by giving kittens the parasympathomimetic drugs, pilocarpine and mecholyl. No such changes were, however, induced by the anticholinesterase drug, diisopropylphosphorofluoridate (DFP) (Wagner, Barbero, and Chernick, 1960), nor by chronic administration of the anticholinergic drug, atropine (Boyd and Jarzylo, 1960).

The rat treated with the sympathomimetic drug, isoproterenol, has been suggested as an experimental model for cystic fibrosis by Mangos, McSherry, Benke, and Spock (1969). Chronic administration of isoproterenol induced hypertrophy of submandibular and parotid salivary glands, with thick, and at times turbid, saliva, with elevated sodium concentration and increased secretion of basic macromolecules. The serum resembled cystic fibrosis serum in containing a factor which caused ciliary dyskinesia.

Earlier studies of submandibular saliva of isoproterenol-treated rats had shown increased storage of calcium as a result of chronic administration, and increased secretion of calcium with acute administration (Dreisback, 1964).

In man, the sympathetic stimulator, isoproterenol, induced increased secretion of calcium, protein, and 
amylase in parotid and submaxillary saliva compared to resting values. This effect of isoproterenol was inhibited by beta-adrenergic blockade but not by alpha-adrenergic blockade (Mandel and Katz, 1968). The parasympathetic stimulator, pilocarpine, induced in the parotid saliva a higher concentration of calcium and protein than did citric acid stimulation, and in the submandibular saliva a greater elevation of calcium, although not of protein (Mandel, Katz, Zengo, Kutscher, Greenberg, Katz, Scharf, and Pintoff, 1967a). In the rat pilocarpine appears to act indirectly on the sympathetic betareceptors via the superior cervical ganglion (Schneyer and Hall, 1966).

In cystic fibrosis patients and in controls, the effect of the parasympathomimetic drug, methacholine, on the submandibular saliva was to increase the turbidity and the concentrations of calcium and protein (Chernick et al, 1961). The antiadrenergic agent, guanethidine, cleared the turbidity and reduced the protein and amylase concentrations of cystic fibrosis submandibular saliva, although it did not lower the elevated calcium concentration (Chernick and Barbero, 1967).

Roberts (1959) suggested that parasympathetic overstimulation in cystic fibrosis may result in oversecretion of mucus, zymogen granules, and sweat, with subsequent exhaustion of enzyme production.

Our results of elevated calcium, protein, and amylase in cystic fibrosis submandibular saliva in association with undissolved components of the zymogen granules are consistent with the evidence suggesting hyperactivity of the autonomic nervous system in cystic fibrosis. The resultant precipitated hydroxyapatite and undissolved zymogen granule contents are postulated as the cause of ductal obstruction in the submandibular gland. Because of the correlation between pancreatic enzymes and calcium, a similar mechanism may be proposed for the cystic fibrosis pancreas, that is, initial hypersecretion leading to blockage by insoluble products, with subsequent autolysis by trapped proteolytic enzymes, and eventual hypofunction.

Despite the higher levels of amylase in parotid saliva compared to submandibular saliva and in cystic fibrosis parotid saliva compared to controls (Mandel et al, 1967b), the calcium concentrations of the parotid secretions are relatively low (Wotman, Mandel, Mercadante, and Denning, 1971). In cystic fibrosis sweat, the calcium is also probably normal or only slightly elevated (di Sant'Agnese and Talamo, 1967). It is postulated, therefore, that in cystic fibrosis parotid saliva and sweat the calcium would not be sufficiently elevated to form insoluble inorganic or protein complexes. In this event a hypersecretion of secretory granules in these glands would lead to an increased concentration of macromolecules. It is possible that these soluble macromolecules are the Mangos factor of cystic fibrosis sweat and mixed saliva which inhibits sodium reabsorption on retrograde perfusion into rat parotid glands (Mangos and McSherry, 1967; Mangos, McSherry, and Benke, 1967), and elevates the sodium concentration in the parotid saliva of the isoproterenol-treated rat (Mangos et al, 1969). Thus a hypersecretion of zymogen granules in all exocrine glands could be a unifying concept which explains the malfunctions of this disorder.

\section{Hypothesis}

From the results presented in this paper and the evidence of other workers propounded in the discussion, the following postulates are made: (1) that submandibular zymogen granules contain calcium; (2) that hypersecretion of zymogen granules is the cause of the elevated calcium level in cystic fibrosis saliva; (3) that precipitated hydroxyapatite and undissolved zymogen granule matrix and spherules are the cause of obstruction in the cystic fibrosis submandibular gland; (4) that a similar pattern of oversecretion of calcium-containing zymogen granules is the cause of obstruction in lungs, pancreas, intestines, and male reproductive tract; and (5) that hypersecretion of relatively low calcium zymogen granules in parotid and sweat glands results in excess of soluble macromolecules, which in some way inhibit salt reabsorption.

\section{References}

Barbero, G. J., and Chernick, W. S. (1966). The role of the autonomic nervous system in cystic fibrosis. In Research on Pathogenesis of Cystic Fibrosis of the Pancreas (Mucoviscidosis), edited by P. A. di Sant'Agnese, pp. 208-222. Wickersham, Lancaster, Pennsylvania.

Blomfield, J. (1972). Zymogen granules in the pathogenesis of cystic fibrosis. In Cystic Fibrosis Club Abstracts, Thirteenth Annual Meeting, Kansas City, Missouri, p. 21.

Blomfield, J., Warton, K. L., and Brown, J. M. (1973). Flow rate and the inorganic components of submandibular saliva in cystic fibrosis. Arch. Dis. Childh., 48, 267-274.

Boat, T. F. (1970). Pathogenesis of turbid submaxillary saliva in patients with cystic fibrosis. In Cystic Fibrosis Club Abstracts, Eleventh Annual Meeting, Atlantic City, New Jersey, p. 30.

Boyd, E. M., and Jarzylo, S. (1960). Chronic atropinization and fibrocystic disease of the pancreas. Canad. med. Ass. J., 82, 821-824.

Caldwell, R. C., and Shackleford, J. M. (1967). A chemical, immunological and electron-microscopic study of centrifuged human submaxillary saliva. Arch. oral Biol., 12, 333-340.

Carlsson, E. I., and Karlsson, B. W. (1972). Enzyme activities and electronmicroscopic structure of rat milk fractions obtained after centrifugation. $Z$. Zellforsch., 131, 223-233.

Chen, P. S., Toribara, T. Y., and Warner, H. (1956). Microdetermination of phosphorus. Analyt. Chem., 28, 1756-1758.

Chernick, W. S., and Barbero, G. J. (1959). Composition of tracheobronchial secretions in cystic fibrosis of the pancreas and bronchiectasis. Pediatrics, 24, 739-745.

Chernick, W. S., and Barbero, G. J. (1967). Reversal of submaxillary salivary alterations in cystic fibrosis by guanethidine. Mod. Probl. Pediat., 10, 125-134.

Chernick, W. S., Barbero, G. J., and Parkins, F. M. (1961). Studies on submaxillary saliva in cystic fibrosis. J. Pediat., 59, 890-898. 
Chernick, W. S., Eichel, H. J., and Barbero, G. J. (1964). Submaxillary salivary enzymes as a measure of glandular activity in cystic fibrosis. J. Pediat., 65, 694-700.

Di Sant'Agnese, P. A., and Talamo, R. C. (1967). Pathogenesis and physiopathology of cystic fibrosis of the pancreas: fibrocystic disease of the pancreas (mucoviscidosis). New Engl. J. Med. 277, 1287-1294, 1344-1352, 1399-1408.

Dorey, G., and Bhoola, K. D. (1972). I. Ultrastructure of acinar cell granules in mammalian submaxillary glands. Z. Zellforsch., 126, 320-334

Dreisbach, R. H. (1964). Effect of isoproterenol on calcium metabolism in rat salivary gland. Proc. Soc. exp. Biol. (N.Y.), 116, 953-956.

Eggstein, M., and Kreutz, F. H. (1955). Vergleichende Untersuchungen zur quantitativen Eiweissbestimmung im Liquor und Eiweissarmen Lösungen. Klin. Wschr., 33, 879-884.

Farber, S. (1942). The experimental production of achylia pancreatica. Amer. J. Dis. Child., 64, 953-954.

Farber, S. (1945). Some organic digestive disturbances in early life. J. Mich. med. Soc., 44, 587-594.

Ferner, H., and Gansler, H. (1961). Elektronenmikroskopische Untersuchungen an der Glandula Submandibularis und Parotis des Menschen. Z. Zellforsch., 55, 148-178.

Goebell, H., Bode, C., and Horn, H. D. (1970). Einfluss von Secretin und Pankreozymin auf die Calciumsekretion im menschlichen Duodenalsaft bei normaler und gestorter Pankreasfunktion. Klin. Wschr., 48, 1330-1339.

Goebell, H., Steffen, C., and Bode, C. (1972). Stimulatory effect of pacreozymin-cholecystokinin on calcium secretion in pancreatic juice of dogs. Gut, 13, 477-482.

Gow, B. S. (1965). Analysis of metals in saliva by atomic absorption spectroscopy. I. Calcium. J. dent. Res., 44, 885-889.

Green, M. N., Clarke, J. T., and Shwachman, H. (1958). Studies in cystic fibrosis of the pancreas: protein pattern in meconium ileus. Pediatrics, 21, 635-641.

Gugler, E., Pallavicini, C. J., Swerdlow, H., and di Sant'Agnese, P. A. (1967). The role of calcium in submaxillary saliva of patients with cystic fibrosis. J. Pediat., 71, 585-588.

Hadorn, B., Johansen, P. G., and Anderson, C. M. (1968). Pancreozymin-secretion test of exocrine pancreatic function in cystic fibrosis and the significance of the result for the pathogenesis of the disease. Aust. paediat. J., 4, 8-22.

Kern, H. F., and Ferner, H. (1971). Die Feinstruktur des exokrinen Pankreasgewebes vom Menschen. Z. Zellforsch., 113, 322-343.

Klein, B., Foreman, J. A., and Searcy, R. L. (1970). New chromogenic substrate for determination of serum amylase activity. Clin. Chem., 16, 32-38.

Kopito, L., and Shwachman, H. (1964). Spectroscopic analysis of tissues from patients with cystic fibrosis and controls. Nature (Lond.), 202, 501-502.

Kopito, L., and Shwachman, H. (1966). Mineral composition of meconium. J. Pediat., 68, 313-314.

Lowry, O. H., Rosebrough, N. J., Farr, A. L., and Randall, R. J. (1951). Protein measurement with the Folin phenol reagent. $J$. biol. Chem., 193, 265-275.

Mandel, I. D., Eriv, A., Kutscher, A., Denning, C., Thompson, R. H., Jr., Kessler, W., and Zegarelli, E. (1969). Calcium and phosphorus levels in submaxillary saliva: changes in cystic fibrosis and in asthma. Clin. Pediat., 8, 161-164.

Mandel, I. D., and Katz, R. (1968). The effect of pharmacologic agents on salivary secretion and composition. II. Isoproterenol, alpha and beta adrenergic blockers. J. oral Therap., 4, 260-269.
Mandel, I. D., Katz, R., Zengo, A., Kutscher, A. H., Greenberg, R. A. Katz, S., Scharf, R., and Pintoff, A. (1967a). The effect of pharmacologic agents on salivary secretion and composition in man. I. Pilocarpine, atropine and anticholinesterases. J. oral Therap., 4, 192-199.

Mandel I. D., Kutscher, A., Denning, C. R., Thompson, R. H., Jr., and Zegarelli, E. V. (1967b). Salivary studies in cystic fibrosis. Amer. J. Dis. Child., 113, 431-438.

Mangos, J. A., and McSherry, N. R. (1967). Sodium transport: Inhibitory factor in sweat of oatients with cystic fibrosis. Science, 158, 135-136.

Mangos, J. A., McSherry, N. R., and Benke, P. J. (1967). A sodium transport inhibitory factor in the saliva of patients with cystic fibrosis of the pancreas. Pediat. Res., 1, 436-442.

Mangos, J. A., McSherry, N. R., Benke, P. J., and Spock, A. (1969) Studies on the pathogenesis of cystic fibrosis: the isoproterenol treated rat as an experimental model. In Proceedings of the Fifth International Cystic Fibrosis Conference, Cambridge, England, edited by D. Lawson, pp. 25-36. Cystic Fibrosis Research Trust, London.

Moore, E. W., and Makhlouf, G. M. (1968). Calcium in normal human gastric juice. A four-component model with speculation on the relation of calcium to pepsin secretion. Gastroenterology, $55,465-480$.

Neal, J. L., Girgis, E. A., and Belmonte, M. M. (1972). Low chymotrypsin activity in cystic fibrosis: enzyme deficiency or enzyme defect? In Cystic Fibrosis Club Abstracts, Thirteenth Annual Meeting, Kansas City, Missouri, p. 9.

Orzalesi, N., Riva, A., and Testa, F. (1971). Fine structure of human lacrimal gland. I. The normal gland. J. submicr. Cytol., 3, 283-296.

Pallavicini, J. C. (1964). Attachment for the Buchler apparatus for use with polyacrylamide gel electrophoresis. Buchler Instruments Inc., Fort Lee, New Jersey.

Roberts, G. B. S. (1959). Fundamental defect in fibrocystic disease of the pancreas. Lancet, 2, 964-965.

Rule, A. H., Kopito, L., and Shwachman, H. (1970). Chemical analysis of ejaculates from patients with cystic fibrosis. Fertil. and Steril., 21, 515-520.

Sato, M., Noguchi, T., Yokoyama, M., and Yotsumoto, M. (1966). On the secretory granules of the serous cell in the human submandibular gland. J. Electron Microsc., 15, 1-14.

Schneyer, C. A., and Hall, H. D. (1966). Autonomic pathways involved in sympathetic-like action of pilocarpine on salivary composition. Proc. Soc. exp. Biol. (N.Y.), 121, 96-100.

Tandler, B., and Erlandson, R. A. (1972). Ultrastructure of the human submaxillary gland. IV. Serous granules. Amer. J. Anat., 135, 419-433.

Wagner, B. M., Barbero, G. J., Chernick, W., and Kim, H. S. (1960). Histochemical studies in cystic fibrosis of the pancreas. Amer. J. Dis. Child., 99, 61-66.

Wallach, D., and Schramm, M. (1971). Calcium and the exportable protein in rat parotid gland: parallel subcellular distribution and concomitant secretion. Europ. J. Biochem., 21, 433-437.

Warton, K. L., and Blomfield, J. (1971). Hydroxyapatitite in the pathogenesis of cystic fibrosis. Brit. med. J., 3, 570-571.

Wotman, S., Mandel, I. D., Mercadante, J., and Denning, C. R. (1971). Parotid and submaxillary calcium in human cystic fibrosis. Arch. oral Biol., 16, 663-665.

Zimmerman, M. J., Dreiling, D. A., Rosenberg, I. R., and Janowitz, H. D. (1967). Secretion of calcium by the canine pancreas. Gastroenterology, 52, 865-870. 